\title{
Values-led management: the guidance of place-based values in environmental relationships of the past, present, and future
}

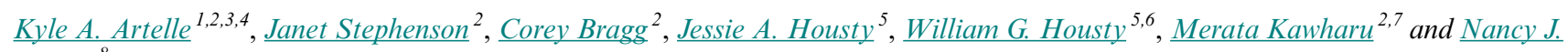
$\underline{\text { Turner }}^{8}$

\begin{abstract}
The prevalence of widespread, human-caused ecological degradation suggests that fundamental change is needed in how societies interact with the environment. In this paper we argue that durable models of environmental relationships already exist in approaches of place-based peoples, whose values connect people to their environments, provide guidance on appropriate behaviors, and structure sustained people-place relationships. To illustrate, we identify and discuss concordant values of indigenous peoples at opposite ends of the Pacific Ocean: the Māori of Aotearoa (New Zealand), and First Nations of the West Coast of Canada. We find that values of relatedness to, respect of, and reciprocity with other species and places correspond with sustained long-term relationships between people and places, and illustrate with examples from both regions. We propose that by integrating a values-led foundation into management broadly, values-led management could enable similar sustained relationships in places where they have been recently disrupted or where they are altogether lacking. We characterize values-led management as being founded on values that underpin stewardship-like relationships between people and place and that in turn guide related objectives, policies, and practices. We examine two contemporary values-led management plans that follow this structure, and provide additional examples of emergent values-led approaches elsewhere. From these we compile a set of questions that might guide the conception of place-based values-led management in decolonizing contexts, in contexts where people have a desire for place-based approaches but have not yet distilled foundational values for guidance, or in contexts where people have a united set of values but have not yet translated them into specific management approaches. We conclude by discussing both the challenges and learning opportunities that the resumption, or commencement, of values-led management might entail.
\end{abstract}

Key Words: First Nations; indigenous; indigenous knowledge; Māori; reconciliation; resource management; social-ecological systems; stewardship; traditional ecological knowledge; values; worldviews

\section{INTRODUCTION}

Global human activities have led to a series of ecological and socio-cultural crises (Vitousek et al. 1997, Hilistis [Waterfall] et al. 2001, Davis 2009, Dick et al. 2012, Turner et al. 2013, Ceballos et al. 2017, Betts et al. 2017), a trend that has not abated in recent years despite growing knowledge of causes and a plethora of policies and actions geared toward addressing them (Ripple et al. 2017, Abson et al. 2017, Ceballos et al. 2017). Given the lack of overall success to date, many have argued that adjustments to policies and market settings are not enough to tackle current ecological and socio-cultural crises, and that fundamental change is needed in how people relate to and draw sustenance from the environment (Martin et al. 2016, Ripple et al. 2017, Abson et al. 2017).

The metaphor of leverage points has been used to describe how creating small changes in one aspect of a complex system, e.g., social-ecological systems, can lead to substantial changes in its overall function or structure (Meadows 1999, Abson et al. 2017). These range from shallow leverage points, where actions are straightforward but unlikely to result in broad changes, e.g., tweaking parameters such as quotas for extracted resources or rates of carbon taxes, to deep leverage points, where actions might be more difficult to implement but more likely to result in fundamental and transformational changes. Meadows (1999) describes the mindset or worldview guiding a given system as a deep leverage point, suggesting that changes to worldviews could have substantial effects on social-ecological systems. However, how worldviews might lead to sustained environmental relationships might seem intangible to many.

We argue that models for relating to and conceptualizing environments already exist in place-based cultures, e.g., indigenous peoples (Roberts et al. 1995, Mihinui 2002, Turner 2005, Atleo 2011, Berkes 2012, Turner and Spalding 2013, Stephenson et al. 2014), with values playing a key, and often overlooked, role in guiding sustained interactions with place. We suggest that insights from these tangible, time-tested, and valuesbased approaches could be applied broadly, providing deep leverage by fundamentally transforming the people-place relationships underpinning management.

\section{PLACE-BASED PEOPLES IN AOTEAROA (NEW ZEALAND) AND WEST COAST OF CANADA}

Place-based peoples, those with deep and lengthy connections to their local environments, have ways of life that have shaped, and have in turn been shaped by, the places they inhabit. Place-based peoples typically have an extensive knowledge of their environment's ecological limits developed through generations of learning by observation and trial and error, and hold values, i.e., guiding principles and protocols that dictate proper conduct, and knowledge that safeguard against exceeding such limits (Berkes and Turner 2006, Turner and Berkes 2006). These relationships have not only allowed for sustained human well-being, but have

\footnotetext{
${ }^{1}$ Earth to Ocean Research Group, Simon Fraser University, ${ }^{2}$ Centre for Sustainability, University of Otago, ${ }^{3}$ Raincoast Conservation Foundation, ${ }^{4}$ Department of Geography, University of Victoria, ${ }^{5}$ Qqs Projects Society, ${ }^{6}$ Heiltsuk Integrated Resource Management Department, ${ }^{7}$ Te Tumu School of Māori, Pacific and Indigenous Studies, University of Otago, ${ }^{8}$ School of Environmental Studies, University of Victoria
} 
Fig. 1. Location of Aoteraoa (New Zealand) in blue, home to the Māori, and the West Coast of British Columbia, Canada, in red, home to many individual Coastal First Nations, referred to collectively herein as "Coastal Peoples."

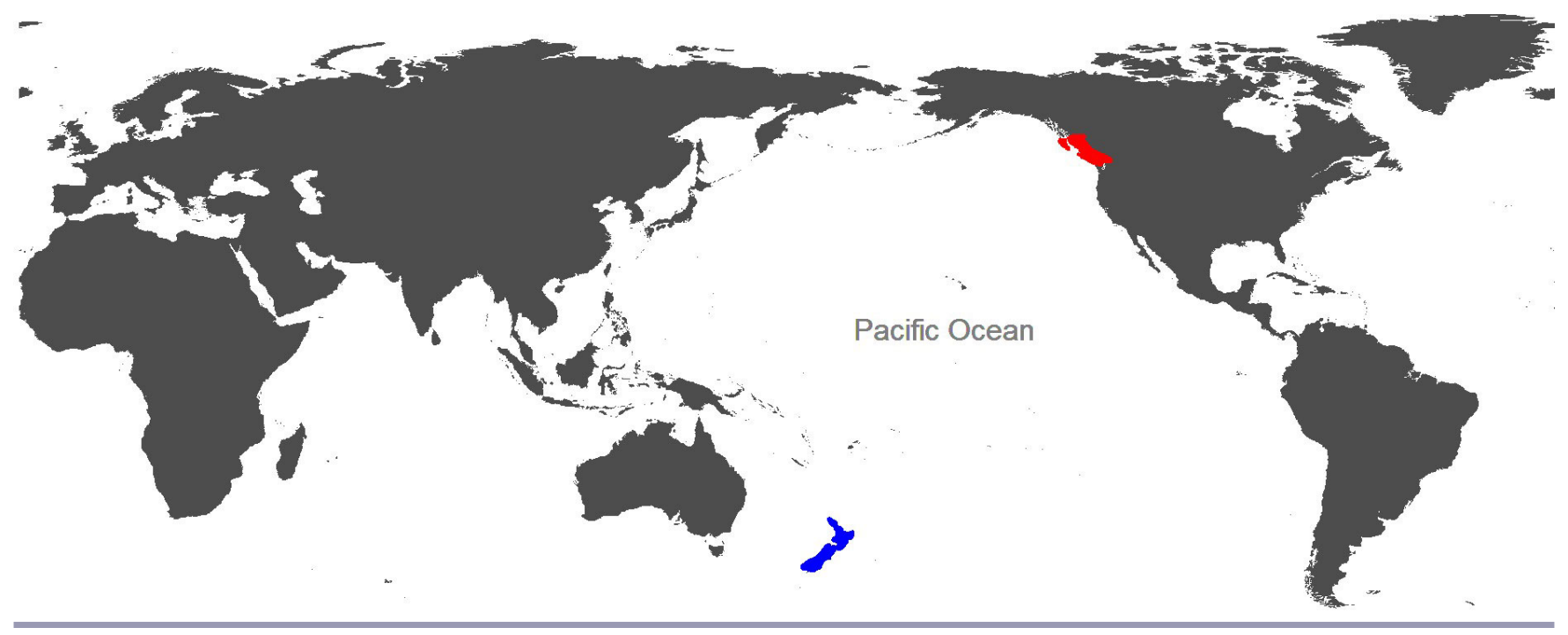

in many cases played important roles in structuring and maintaining the function and diversity of broader ecological communities (Bird and Nimmo 2018). Whereas we predominantly discuss examples from indigenous peoples herein, we note that there are others with long-term, place-based relationships such as traditional farming communities (Altieri 2004). We also note that the potential for place-based relationships are not limited to communities where such relationships currently exist, but might also be revitalized in places where they have recently been interrupted, or developed anew and intentionally elsewhere.

We focus on concordant values of indigenous peoples from two disparate regions: Aotearoa (New Zealand) in the south Pacific, and the West Coast of Canada (Fig. 1). Both regions and cultural groups provide examples of long-term relationships to place. Māori migrated to Aotearoa from Polynesian islands by oceangoing canoes around 700 years ago (Wilmshurst et al. 2008, Tapsell 2014, Anderson et al. 2016, Walter et al. 2017) and quickly established themselves across the previously unpopulated lands. Across the Pacific, the West Coast of Canada is inhabited by many culturally distinct First Nations (hereafter Coastal Peoples) who have inhabited the region since time before memory (at least 14,000 years according to archeological surveys; Muckle and Gauvreau 2017).

By the time of European contact, people in both regions had developed stewardship practices guided by complex and responsive understandings of local ecologies (Stephenson et al. 2014, Turner 2014, Kahui and Richards 2014, West 2017). These practices were (and still are) driven by overarching values that prohibit overexploitation of, or disrespect to, other people, species, or places embodied in, for example, Ğvịlás (Haíłzaqv Law) in the Haîłzaqv (Heiltsuk) Nation of Coastal British Columbia (Hilistis [Waterfall] et al. 2001, Heiltsuk Tribal Council 2005, Housty et al. 2014), and tikanga Māori (a system of values and practices that dictate proper conduct) in Aotearoa (Roberts et al. 1995, Mead 2003).
These regions (as elsewhere) also share a similar history of interruptions to place-based, values-led approaches to environmental interactions as a result of European colonization. In addition to the devastating impacts on ways of life, including health, welfare, and cultural knowledge and practices (Harris 2011, Ka'ai-Mahuta 2011, Dick et al. 2012, King 2012, Turner et al. 2013, McCarthy et al. 2014, Manuel and Derrickson 2015, Sinclair and TRC members 2015), colonization also resulted in substantial environmental change and loss of species and habitats (Belich 2007, Turner et al. 2008, 2013, West 2017).

In recent years, addressing these historical injustices has begun (UN General Assembly 2007, Atleo 2011, Waitangi Tribunal 2011, Manuel and Derrickson 2015). Whereas the effects (and, in many cases, drivers) of colonization are ongoing, a resurgence of languages and cultural revitalization is occurring across both regions, including resumption of recently interrupted relationships with places, and, in some instances, comanagement arrangements or complete transferral of management and control of land back to its original inhabitants (Parsons et al. 2017). This paper is situated in the contemporary context, drawing insights from peoples' relationships with places in the past, but also the continuation and resurgence of these relationships in the present.

\section{THE IMPORTANCE OF VALUES IN SHAPING ENVIRONMENTAL APPROACHES}

The importance of indigenous knowledge (also known as traditional ecological knowledge) is increasingly being recognized both locally and globally, with a growing focus in academic research, consideration in relationships between indigenous and colonial governments, and increased awareness among nonindigenous members of the public (UN General Assembly 2007). Indigenous knowledge is widely recognized as a holistic and interconnected way of knowing, in which practices, knowledge transmission, institutions, beliefs, values, and other aspects of worldviews are all inseparable (Turner et al. 2000, Stephenson and Moller 2009, Berkes 2012). However, the scope 
of consideration by outside researchers and governing agencies is often limited to data points, such as specific environmental practices or subsets of environmental knowledge, without recognizing the underlying values (Hilistis [Waterfall] et al. 2001, Simpson 2001, Turner 2005, White 2006, Turner et al. 2008, Berkes 2012, Kimmerer 2013, Turner and Spalding 2013). The reasons for overlooking the less tangible aspects of indigenous knowledge are varied and beyond the scope of this work (though see Simpson 2001). However, ignoring the critical role of underlying values represents a lost opportunity not only for respectful cross-cultural relationships (Simpson 2001, Ruru 2012) but also, we argue here, for advancement of effective stewardship practices. Although we focus on environmental values for discursive purposes herein, we caution against the misinterpretation that these are the only important aspects of indigenous cultures (Simpson 2001).

Environmental values evolve from relationships between people and their environments and concomitant learning over generations. As described in origin stories and anthropological records, when people first arrive in a new place they may begin with little knowledge of or connection to it (Atleo 2011). Initially, species or ecosystems might be overexploited leading to ecological crises. For example, early settlement of Aotearoa by Māori led to the loss of some native fauna, most notably moa, large flightless birds (Holdaway and Jacomb 2000, Wehi et al. 2018). However, experiencing environmental crises, coupled with careful ecological observations through time, can underpin environmental learning (Berkes and Turner 2006, Berkes 2012, Wehi et al. 2018). As people spend more and more time in a given place, their practices often become increasingly adapted toward sustainable relationships that are shaped by the biological and geographical characteristics of that particular locale. Evolving norms and social restraints that safeguard against overexploitation are passed down through generations, reducing the risk of repeating past mistakes, with concurrent slowing or reversals of ecological degradation (Berkes and Turner 2006, Turner and Berkes 2006). Importantly, these evolving adaptive approaches are supported not only by accumulated knowledge, but also are underpinned by coevolving values that guide appropriate conduct and behavior (Roberts et al. 1995, Mead 2003, Berkes and Turner 2006, Turner and Berkes 2006, Kitson and Moller 2008, Harmsworth and Awatere 2013, Wehi et al. 2013). It is these values that ultimately guide sustained relationships with place.

Here, we refer to values as aspects of worldview that provide guidance on proper conduct, and hence play an important role in shaping practices (Atleo 2011, Turner and Spalding 2013, Chan et al. 2016), as opposed to the homonymous definition related more to valuation or worth, e.g., recreational values of a given landscape. We specifically focus on guiding values that link people to, and enable sustained relationships with, place. For illustrative purposes, we identify three such values that are commonly described by Māori and Coastal Peoples from both regions, who share these values despite a lack of shared lineage. We focus on describing these three values neither as prescriptions nor as an exhaustive list, but instead as tangible examples of how values shape people's environmental relationships. Other values with relevance to place-based relationships exist in both regions, and might have similar importance in place-based relationships.

\section{Relatedness}

For Māori and for Coastal Peoples, as for many other indigenous peoples, there is no fundamental distinction between humans and other species: all are related and have a shared history (Rangihau 1992, Garibaldi and Turner 2004, Hook et al. 2007, Brown and Brown 2009, Atleo 2011, Harmsworth and Awatere 2013, Turner and Spalding 2013). The Māori worldview incorporates a seamless connectedness between people and the natural world, in that people are not only related via their human ancestry, but also related to the physical world: people are descended from Papatūānuku (Earth Mother) and Rangi-Awatea (Sky Father) and in turn related to all natural elements and all living things (Rangihau 1992, Hook et al. 2007). Similarly, Haíłzaqv and other Coastal Peoples' history describes a time when all animals had the ability to transform into humans and vice-versa (Atleo 2011; Housty 2012, Presentation to the National Energy Board Enbridge Hearings, https://www.youtube.com/watch?v=4UOouXAwmPE). In both regions, continued relationships with these relatives are reflected in names, songs, sayings, symbols, ceremonies, and language.

In both regions, inter-relatedness is not only with other species but also with the land itself (Turner 2005, Brown and Brown 2009, Dick et al. 2012). As with species-relatives, places are integral components of identity (Johnson and Hunn 2010, Stephenson et al. 2010): they comprise key food places, places central to stories and song, places of creation stories, and places associated with names, chieftainships, authority, and identity (Hilistis [Waterfall] et al. 2001, Mead 2003, Heiltsuk Tribal Council 2005, White 2006, Panelli and Tipa 2007, Brown and Brown 2009, Cuerrier et al. 2015). Land is imbued with cultural values (Turner 2005, Cuerrier et al. 2015, Lyver et al. 2016), as opposed to a resource defined solely by monetary value. The deep connection between people and place is further reflected in language; for example, in te reo Māori (Māori language), a person's whakapapa, loosely translated as genealogy, relates not only to human ancestors but also to the land to which they are connected (Roberts et al. 1995, Rotarangi and Russell 2009, Ruckstuhl et al. 2013, Timoti et al. 2017). The term whenua means both placenta and the relationship between people and land (Mead 2003, Timoti et al. 2017). Similarly, Te u kai po means both the land on which you were brought up, and the act of breastfeeding (Roberts et al. 1995).

The connection, embeddedness, identity, and other corollaries of a deep inter-relationship with species and places inherently leads to supportive, nurturing, and protective relationships (Bhattacharyya and Slocombe 2017). It is human nature to treat loved ones and relatives with care and respect, and for Coastal Peoples and Māori this extends to the broader ecological community, reflected for example in countless stories teaching that what affects the environment directly affects people (Turner 2005, Durie 2010).

Across many Coastal Peoples' territories, Qaikas Nan, the great grizzly bear (Ursus arctos horribilis), is a relative of immense cultural importance that serves as an example of how relatedness guides supportive relationships (Housty et al. 2014; Clark and Slocombe 2009 also discuss grizzly-human relationships in northern Canada). First Nations in this area today use a multipronged approach to taking care of this relative, for example, leading substantial research efforts, banning trophy hunting 
under tribal law, and protecting extensive tracts of habitat and key food resources from industrial activity. This is in contrast to the centralized approach to trophy hunt management imposed by the Province of British Columbia (see British Columbia Ministry of Environment, Fish, Wildlife and Habitat Branch 2010), an approach that used relatively imprecise data and subjected grizzly populations to considerable risks (Artelle et al. 2013) until a province-wide moratorium was enacted in 2017. These different management approaches are driven by very different worldviews: one that sees grizzly bears as close relatives and teachers (Housty et al. 2014), another that sees wildlife as resources to be managed for maximum benefit of stakeholders, mostly individual hunters (e.g., Treves et al. 2017).

A similar difference in perspective is highlighted by the treatment of the Whanganui River, the longest navigable river in Aotearoa, which has been substantially modified since European colonization (Magallanes 2015). In recent years, Māori-led legal efforts have resulted in a Deed of Settlement with the Crown that has given the river legal personhood as an indivisible and living entity (Hutchison 2014, Magallanes 2015), with management based, for example, on the concept that "the River is the source of spiritual and physical sustenance" (Magallanes 2015, New Zealand Government 2016:14). Legal outcomes and protections from this shift reflect the Māori worldview that sees the river as a close, living relative, and an important component of personal and cultural identity, rather than simply as a resource with economic value (Magallanes 2015).

\section{Respect}

Across Māori and Coastal Peoples, respectful relationships among other people, species, and the broader environment are of central importance, with laws and stories of retribution for disrespectful actions known and understood from an early age (Roberts et al. 1995, Mihinui 2002, Turner 2005, 2014, Atleo 2011). One manifestation of this is the imperative to respect nonhuman kin by not wasting their gifts, to take only what is needed and nothing else (Hilistis [Waterfall] et al. 2001, Brown and Brown 2009). For example, Coastal Peoples' technologies of weirs, fish traps, and nets represent highly efficient methods of capture of salmon (Anderson 1996, White 2006, Thornton et al. 2015, Mathews and Turner 2017, Atlas et al. 2017). However, laws such as Ğvịlás deter against using these technologies to excess and wasting the gift of salmon (Hilistis [Waterfall] et al. 2001), a principle reinforced by cultural practices. One such practice, the First Salmon Ceremony, honors returning salmon and coincides with a ban on fishing at the beginning of the spawn, allowing large numbers of salmon to reproduce, maintaining productive populations (Jones 2000, Turner and Berkes 2006, Turner et al. 2013, Stephenson et al. 2014, Thornton et al. 2015). Unfortunately, this approach was disrupted by colonial, centralized fisheries management that saw salmon as a resource to be maximally exploited, without embedded taboos of respect to protect against overexploitation, with often catastrophic effects coast-wide (Turner et al. 2013).

Respect is also shown by Māori who engage in the cultural harvest of tīti (Sooty Shearwater, Ardenna griseus) on small islands in southern Aotearoa. This traditional harvest is carefully managed through the limited number of families with hereditary rights permitted to participate. Detailed tikanga (rules) include limits to when the islands can be accessed, provisions toward the protection of habitat and adult (breeding) birds, and directives to minimize waste (Kitson and Moller 2008). This largely sustainable harvest (e.g., Moller et al. 2009) is underpinned by the responsibility for ensuring that future generations will be able to continue to harvest, which requires respect for, and guardianship of, the birds and their environment (Kitson and Moller 2008).

The value of respect goes beyond population-level sustainability of harvests, but also shapes all aspects of people's relationships with other species and places, including at the level of individual organisms. For example, researchers studying bears in Coastal Peoples' territories are required to follow respectful approaches. Elsewhere, grizzly bear research commonly involves tranquilizing individuals, removing teeth for age assessment, and attaching radio collars for movement tracking, all of which are stressful and detrimental to captured individual bears (Cattet et al. 2008). This is incongruent with the respectful relationships required by Coastal Peoples. Instead, Coastal Peoples require (and employ) noninvasive approaches for research in the area, with information gleaned through passively collected hair samples without direct interactions or stresses to the bears (Bryan et al. 2013, 2014, Housty et al. 2014, Service et al. 2014, Adams et al. 2017; see also Darimont et al. 2008 for scat-based approaches). Research on tìtī provides a parallel, where strong teachings are in place to protect the mana (honor) and mauri (life force) of the breeding grounds and adult individuals being studied. These teachings translate to strict controls on research activities, for example restricting when sites can be accessed, where soil can be sampled, and limiting methodologies that might affect the well-being of individual birds (Moller et al. 2009). These examples of tightly controlling research, including projects geared toward sustainability of key cultural species, in part reflect a difference of treating species with the deference required for a relative, as compared to the objectified treatment of a research subject.

\section{Reciprocity}

A corollary to respectful interactions is the requirement of reciprocity. For Māori and Coastal Peoples, this relates not only to human relatives but also to the broader environment (Ruru 2012, Turner and Spalding 2013, Comberti et al. 2015). The right to use a resource is often contingent on the responsibility to maintain it, protect it, and honor it (Roberts et al. 1995, Mihinui 2002, Stephenson 2002, Heiltsuk Tribal Council 2005, Turner 2005, White 2006, Kawharu 2010). For example, in te reo Māori, the term mana whenua, which is commonly used in Māori-Māori or Māori-Crown/local government contexts, emphasizes the mana or authority of both lands and of peoples, and the reciprocity between them (Kawharu 2000). The concept of kaitiakitanga, roughly translated as stewardship, is founded on reciprocity: "Deriving economic or social benefit from the resources gifted to them by [spiritual ancestors] must be balanced by the responsibilities and adherence to the ethic of reciprocity toward Papatūānuku and her other children" (Panelli and Tipa 2007:455).

One example of how this reciprocity plays out currently is the relationship among bears and people in the Kitasoo/Xai'xais Nation, which owns and runs the Spirit Bear Lodge, a communityled ecotourism business named after the Spirit Bear, a whitecoated black bear that occurs in the region. The growth of this 
company has resulted in substantial benefits for the community, including improving employment and supporting cultural resurgence (Lemelin et al. 2015; Douglas Neasloss 2016, personal communication). In turn, the organization contributes to multifaceted, region-wide conservation efforts, including support of the Spirit Bear Research Foundation, which facilitates research on the conservation and ecology of bears throughout the territory and raises awareness of their importance (see https:// spiritbearfoundation.com).

Similar examples of reciprocity exist in Aoteroa. A parallel ecotourism example is Whale Watch Kaikoura, a business founded and co-owned by the Ngāti Kuri hapū (subtribe) of Ngai Tahu (Spiller and Bhowmick 2014). Ngāti Kuri consider the whales kaitiaki, or guardians, who look after the spiritual and physical safety of the people, while people in turn are kaitiki for the whales (McIntosh et al. 2014): ecotourism here has enabled economic benefits for the hap $\bar{u}$, which in turn has worked tirelessly for habitat conservation, for protection from potential damage from oil development, and from other threats (see http://www. whalewatch.co.nz). In relation to the long-established practices on the tìti islands, birders follow the teachings that if they care for the state of the land, the birds will continue to return and thus enable continued harvest for future generations (Kitson and Moller 2008).

Reciprocal relationships among people further strengthen relationships with other species and places. For both Coastal Peoples and Māori, generosity is important, and to provide for others requires maintaining healthy and robust ecosystems. For example, an important part of the Heiltsuk identity is related to the quality and quantity of the Nation's ł'qst (edible seaweed, Pyropia abbottiae) and hạn t (eggs from herring, Clupea pallasii), that are given and/or traded among neighboring friends and relations (Housty 2012, Gauvreau et al. 2017). The ability of Māori Peoples to exercise manaakitanga (hospitality and consideration for others), such as in providing kai (food) from one's home, is of similar central importance for expressing and strengthening relationships, expressing mana and identity, and for expressing consideration of other people and species (Roberts et al. 1995, Mihinui 2002, Dick et al. 2012). In both regions, items gifted or traded are specific to people and place. In contrast to a more commodified economy where resources are fungible, these items cannot be replaced with different items of similar monetary value (Garibaldi and Turner 2004, Dick et al. 2012). Maintaining the human reciprocal relationships of giving and trading thus requires maintaining reciprocal relationships with the resources themselves. This further reinforces the corollary of interrelatedness: people must not only help one another, but also their local species and places (Atleo 2011).

Values including, but not limited to, relatedness, respect, and reciprocity, have arisen in parallel amongst Māori and Coastal Peoples, we argue, because they were critically important in sustaining a healthy environment and society. Such guiding values underpin practices that enable sustained, long-term associations with place, and provide guidance for correct actions in situations where specific rules do not exist.

\section{VALUES-LED MANAGEMENT}

"Māori people have a particular way of dealing with the present. There is a well-known aphorism that says Māori walk backwards into the future, that is, they take the past with them in advancing into the unknown" (Kawharu 2010:222). Given the foundational association between guiding values and long-term and sustained relationships between people and environments, we propose that a values-led approach might prove critical for any situation where people are seeking sustainable interactions with the environment.

We define values-led management as management with practices, policies, and objectives underpinned and guided by coherent and consistent values, particularly those that connect people to place (at any scale) and that can form the foundation for sustained relationships. Whereas management explicitly guided by any values fits this description, we refer specifically to those values related to environmental interactions. Although management implies a top-down process that aligns with neither the approaches we have described above (Lertzman 2009, Turner 2014), nor the values that guide them, we use the term environmental management here given its wide use to describe intentional systems of interacting with the environment. We also note that whereas place-based approaches are not directly equivalent to the Western concept of environmental sustainability, they aspire to similar outcomes: sustaining healthy and productive environments that support human well-being (Harmsworth and Awatere 2013).

Values play a role in shaping any relationship; however, the distinction in the approach described here is that these values are made explicit. By contrast, the values underlying specific policies used in Western-based management systems are often neither recognized nor explicitly articulated. For example, some management decisions are assumed or claimed to be based purely on knowledge from natural sciences (Artelle et al. 2014, 2018), despite sometimes contradicting evidence (e.g., Horwitz and Calver 1998, Artelle et al. 2014, Popescu et al. 2016, Darimont et al. 2018). However, although the natural sciences provide information on how the world works and may predict future outcomes (e.g., "will a particular action likely lead to population declines?"), they do not determine the underlying values that ultimately drive management (e.g., that answer questions such as "why should we protect against population declines?"; Nelson et al. 2011, Darimont et al. 2017). Understanding and, importantly, articulating the values underlying a management system might provide crucial insight into whether it might be expected to enable sustained relationships. For example, management founded on values that have been associated with a connection to place and sustained relationships elsewhere might be predicted to have a higher likelihood of success than management founded on values such as maximizing financial profit or continuous economic growth (Martin et al. 2016).

In considering how a values-led management system might operate in any context (indigenous or non), we suggest that it could have the following key attributes (Fig. 2). The approach is built on a foundation of core values specific to the relationship between a given community and its environment (roots of management). These guide proper ways of conduct with one another, with nonhuman lifeforms, and with place. The values are translated into environmental management objectives (primary branches in Fig. 2), which in turn, guide specific policies (e.g., rules and laws, formal or otherwise; secondary branches in Fig. 2). Finally, these policies determine the desirable practices and ways of engaging with specific places and/or species (leaves or shoots in Fig. 2). 
Fig. 2. Representation of values-led environmental approaches, with each level building from those below. Values (roots of the tree) that connect people to place at a given scale form the foundation of the approach but are often not obvious to outside observers. These values combined inform the rest of the approach, supporting environmental objectives, which in turn support specific policies, which in turn guide individual practices. All aspects of the approach are mutually supportive; institutions that set and enforce objectives and policies link values and actual practices in the same way that branches link roots to leaves in a tree. The approach also evolves through time; just as growth of leaves supports growth of the rest of the tree, including its roots, and vice versa, so too do evolving practices drive changes in overall management, including guiding values, and vice versa.

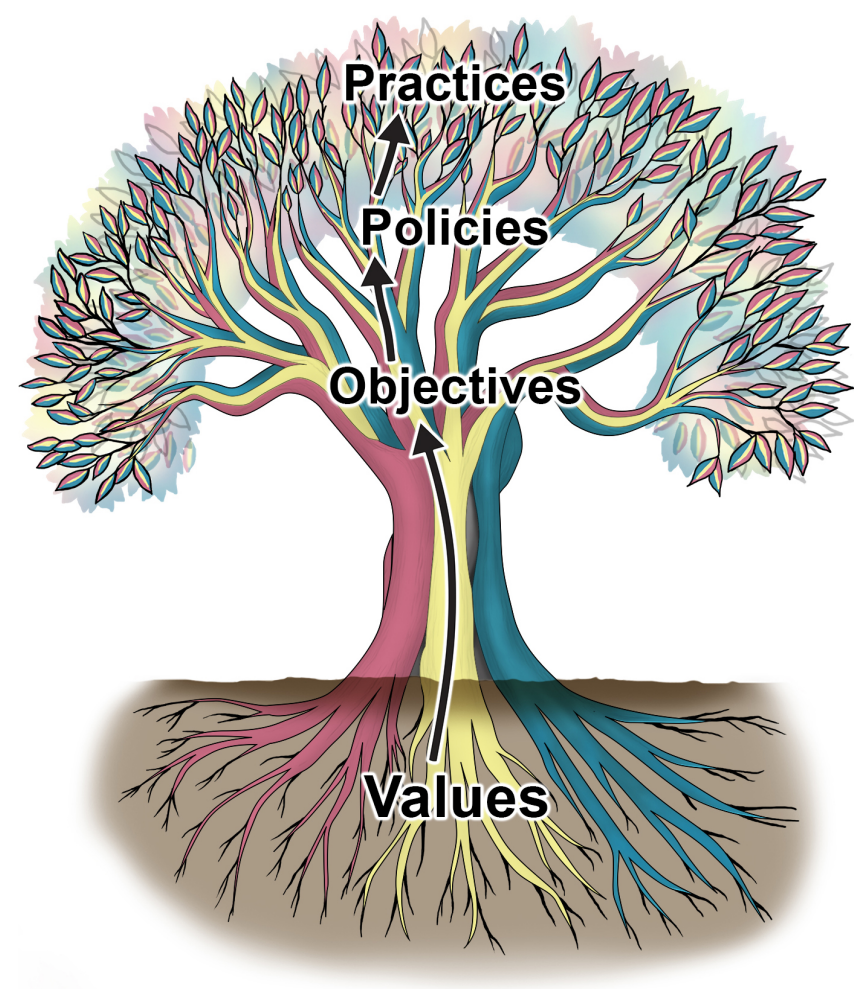

Each of these aspects of management is guided by, and supported by, the aspect that underpins it, providing a coherent and holistic approach to environmental management: each practice is guided by policies that achieve objectives in line with overarching and guiding values, with congruence across interactions with the environment. Although the values guiding this system are not always obvious or visible to outside observers, they form its ultimate foundation.

This nested and focused structure parallels the natural sciences, where effective research aims to achieve well-defined objectives (e.g., Platt 1964, Sullivan et al. 2006, Mangel 2011). The intent of a values-led approach is also comparable with attributes of bestpractice environmental management (O'Riordan 2014), with the critical difference that its foundation comprises explicitly understood values that reinforce people's ongoing relationships with and responsibilities to their local environment.

Notably, we do not suggest that values alone are sufficient for effective management. Although values form the foundation in this system, they require institutions to enact them (e.g., the other elements in Fig. 2). At the individual level, it is well established that people's values can fail to translate into their actions or behaviors. This can be in part because of competing values, selfinterest, or because extenuating circumstances might divert individuals from fully enacting their own or their society's values (Thøgersen and Grunert-Beckmann 1997, Barr and Gilg 2007). For this reason, for values to form the basis of environmental management approaches they need to be supported by policies and practices with appropriate institutions at all levels of the management tree. Contemporary indigenous management plans provide examples of how this can be achieved.

\section{Examples of values-led indigenous management plans}

In Canada and Aotearoa, indigenous management plans have been produced in the past two decades to communicate peoples' values and perspectives in planning contexts, sometimes in response to legal requirements for such information to be in written form (Thompson-Fawcett [Ngāti Whātua] et al. 2017). We use two examples to illustrate how these plans follow the overall structure described in Figure 2.

The Te Rūnanga o Kaikōura Iwi Environmental Management Plan (Te Rūnanga o Kaikōura 2007), developed by Ngāti Kuri, describes values and policies for the Kaikoura region of Aotearoa's South Island. The plan begins with a greeting, describing hapu connections to the landscape and the plan's overall purposes. It then introduces the values underpinning the plan, clearly articulating that the plan is led by values, not policy: "These are the values we stand on. They set the boundaries for our decisions. It is our values that should create the parameters of how we interact with resources, not an Act" (Te Rūnanga o Kaikōura 2007:32). These values include the following: (1) kaitiakitanga: reciprocal guardianship: "Papatūānuku (Earth Mother) sustains the people, and the people must in turn ensure that their actions do not compromise the life supporting capacity of the environment" (p. 32); (2) rangatiratanga and independence: empowerment of the hapa to exercise authority over control of the area and to act as kaitiaki; (3) whakapapa and türangawaewae: speaking to the familial interconnections between people and place, i.e., inter-relatedness; (4) mana of the tūpuna: ensuring that the influence and knowledge of the ancestors is respected; and (5) well-being of Ngāti Kuri: that the health and well-being of people is important in any management and decision making. The plan then describes issues and the objectives for addressing them, e.g., development in the region has the potential for negative impacts on the area, therefore "Rūnanga o Kaikōura looks for balance between maintaining Kaikōura as a beautiful place to live and visit, and protecting the natural environment and cultural heritage" (p. 98), followed by specific enabling policies to guide practices, e.g., policies regarding residential developments, farming, and gravel extraction.

The Haida Gwaii Marine Plan (Marine Planning Partnership Initiative 2015) describes the long-term approach to management and conservation of Haida Gwaii's (British Columbia, Canada) 
Table 1. Examples of resurgent values-led management in Canada and Aotearoa (New Zealand)

\begin{tabular}{|c|c|}
\hline Location & Explanation \\
\hline $\begin{array}{l}\text { Great Bear Rainforest, British } \\
\text { Columbia, Canada }\end{array}$ & $\begin{array}{l}\text { A new protected area designation of "Conservancy" has been developed in the parks system that explicitly } \\
\text { recognizes First Nations interests in the land, and, guided by local values, seeks to preserve and maintain } \\
\text { social, ceremonial, and cultural uses (Turner and Bitonti 2011). }\end{array}$ \\
\hline $\begin{array}{l}\text { Haida Gwaii, British Columbia, } \\
\text { Canada }\end{array}$ & $\begin{array}{l}\text { The Gwaii Haanas National Park Reserve, National Marine Conservation Area Reserve, and Haida Heritage } \\
\text { Site increasingly reincorporates Haida values into stewardship, protecting ancient relationships among people } \\
\text { and place, and strengthening legally entrenched ecological protections (in both Haida and Canadian law; } \\
\text { Ruru 2012) }\end{array}$ \\
\hline Salish Sea, British Columbia, Canada & $\begin{array}{l}\text { WSÁNEĆ and Hul'qumi'num First Nations and Parks Canada are working together to restore clam gardens } \\
\text { in the Gulf Islands National Park Reserve (see } \underline{\text { http://www.pc.gc.ca/eng/pn-np/bc/gulf/natcul/natcul6/natcul6b. }} \text {. } \\
\text { aspx), a millennia-old, place-based, and values-led approach to aquaculture supporting ecological and human } \\
\text { well-being (Groesbeck et al. 2014, Augustine and Dearden } 2014 \text {, Lepofsky et al. } 2015 \text {, Jackley et al. 2016) }\end{array}$ \\
\hline $\begin{array}{l}\text { Tla-o-qui-aht Tribal Park, British } \\
\text { Columbia, Canada }\end{array}$ & $\begin{array}{l}\text { Park design and implementation is guided by Tla-o-qui-aht values and priorities independently of colonial } \\
\text { institutions, "as a projection of sovereignty over contested terrain, or an assertion of Tla-o-qui-aht rights and } \\
\text { title" (Murray and King 2012:389). Whereas some outcomes of this tribal park might converge on the } \\
\text { ecological protection sought through existing protected areas, it differs in being guided by the Tla-o-qui-aht } \\
\text { worldview which, for example, sees the people as key components of the social-ecological integrity of the area } \\
\text { (as in Berkes 2012). }\end{array}$ \\
\hline Ngai Tūhoe territory, Aotearoa & $\begin{array}{l}\text { The Te Urewera Act of } 2014 \text { reclassified a large, ecologically and culturally rich tract of land from a national } \\
\text { park to a comanagement arrangement with Ngai Tūhoe iwi that gives Te Urewera legal personhood in its own } \\
\text { right. This new arrangement is founded on the importance of incorporating Tūhoe customary values and } \\
\text { laws, recognizing inherent rights of Tūhoe to the land, and recognition that "Māori are perfectly capable of } \\
\text { conserving New Zealand treasures at least as well as Pākehā [New Zealanders of European descent] and } \\
\text { departments of State" (Ruru 2014, Section 4). }\end{array}$ \\
\hline Aotearoa & $\begin{array}{l}\text { Under the Resource Management Act 1991, which refers specifically to the value of kaitiakitanga } \\
\text { (stewardship), all regional and territorial councils with responsibility for environmental management are also } \\
\text { required to take into account any iwi environmental management plans for a given area (Thompson-Fawcett } \\
\text { [Ngāti Whātua] et al. 2017). There are now approximately } 190 \text { such plans that are typically founded by core } \\
\text { values for the tribe or subtribe, and offer a holistic approach to management in each territory. }\end{array}$ \\
\hline
\end{tabular}

coastal and marine areas. It similarly begins by describing the context of the planning process. It then describes Haida ethics and values, stating that "[these] underlie the approach to marine planning on Haida Gwaii and are considered to be the foundation of the Marine Plan" (p. 11). The values described (see Jones et al. 2010) are (1) Yahguudang or Yakguudang, respect for all living things; (2) 'Laa guu ga kanhlln, responsibility to manage and care for the land and sea; (3) Gina 'waadluxan gud ad kwaagiida, interconnectedness: everything depends on everything else: interrelatedness between all aspects of the environment; (4) Giid tll'juus, balance: the world is as sharp as the edge of a knife, and balance is needed in all interactions with the environment; (5) Gina k'aadang.nga gii uu tl' k'anguudang, seeking wise counsel: incorporating traditional knowledge with new ideas and information in decision making; and 6) Isda ad diigii isda, giving and receiving: the notion of reciprocity among people, other species, and places. The plan then describes specific goals, e.g., conservation of marine ecosystems, sustainable ocean uses and activities, strategies to achieve each goal, and recommended policies for implementing those strategies, e.g., areas where specific activities are permitted or prohibited. These two examples (of many, e.g., West Coast Environmental Law [date unknown], Clayoquot Sound Scientific Panel 1995, Heiltsuk Tribal Council 2005, Te Rūnanga o Kaikōura 2007, Thompson-Fawcett [Ngāti Whātua] et al. 2017) show how explicit values can underpin a consistent framework of objectives and practices that broadly connect people to place.

\section{Additional examples of values-led approaches}

There are other examples of resurgent values-led management in Canada and Aotearoa (Table 1). The values guiding each may differ, and the recentness of changes might make assessments of changes in realized environmental relationships difficult. However, in each case values intentionally guide environmental management and provide the foundation for resurgence of timehonored, place-based management practices.

There are also examples of newly emerging values-led and placebased management in other contexts. For example, the permaculture movement is at its core place-based, and recognizes the connections between people's actions and broader environments, and builds upon connections among people and places, resulting in a nurturing people-place relationship similar to the place-based examples provided above (Mollison et al. 1991).

Values-led responsibility can also extend beyond scales that are more typical of historical place-based relationships. For example, although recent protests involving the North Dakota Access oil pipeline were initiated by indigenous peoples on whose land the pipeline was to cross (Yohannan 2016), participants joined from across the world. Many participants described themselves as water protectors, suggesting guiding values of responsibility and reciprocity might be applicable to places beyond one's immediate environment.

There are also encouraging shifts toward place-based approaches from within the management realm itself, including the recent interest in ecosystem-based management (EBM) in both Canada 
and Aotearoa (Clayoquot Sound Scientific Panel 1995, Green 2007, Price et al. 2009, National Science Challenges 2017), though we argue that this paradigm falls short of the values-led approaches described herein. The shift to EBM recognizes that holistic consideration is needed of all components of ecosystems, including people, an important evolution from management focused on individual species, with different and sometimes opposing policies and practices being applied to different elements of ecosystems, e.g., separate management of predators and prey (Darimont et al. 2010, Artelle et al. 2016, Adams et al. 2017). However, whereas EBM might recognize the interconnections between people and the environment, its implementation is rarely founded on place-based values (though see Jones et al. 2010, Kahui and Richards 2014, and Marine Planning Partnership Initiative 2015 for discussion on intersection of values-led management and EBM). By not addressing underlying values and worldviews, implementation of EBM might not have the deep leverage to bring about fundamental changes to overall environmental interactions (Meadows 1999, Abson et al. 2017). Moreover, EBM often presents de novo approaches to relationships with the environment. We suggest that applying a values-led foundation to EBM and other more holistic approaches offers a way to recognize and carry forward the ancestral-based environmental learning that place-based societies have developed, and to benefit from the underpinning and guiding values.

\section{DISCUSSION}

In this article we integrated insights from values-led approaches to environmental interactions into a framework for codified values-led management as a means to apply deep leverage to fundamentally alter and improve present-day human relationships with our environments. To better contextualize the potential of this approach, we now discuss some realities that need to be considered, while also exploring potential opportunities and avenues for moving forward.

\section{Postcolonial realities of present-day indigenous communities}

The examples of indigenous approaches used herein have served to illustrate key attributes of values-led management, rather than to comprehensively describe the realities of present-day indigenous communities, many of which are still suffering the long-term effects of colonization including loss of access to land, wealth disparities, and impacts on people's health and well-being (Mikaere 2011, Sinclair and TRC members 2015). Such communities may have limited capacity currently to engage in development (or resumption) of values-led management approaches as described. Moreover, some indigenous communities are highly urbanized, which might make connections to the land and its original species more difficult than in past generations (Paringatai 2014). The strengthening or resumption of relationships to place in contemporary contexts might require addressing many of these fundamental hurdles. The increasingly broad awareness of, and, to varying degrees, addressing of, social injustices and legacies of colonization in Canada and Aotearoa and at the international level, e.g., the United Nations Declaration on the Rights of Indigenous Peoples (UN General Assembly 2007) might provide important first steps, though there is considerable work yet to be done.

\section{Opportunities for walking backwards into the future}

Indigenous peoples, like all peoples, have always adapted and evolved as circumstances changed (Turner and Spalding 2013, Parsons et al. 2017). As such, an approach to environmental interactions built on or inspired by ancestral knowledge does not preclude the development or incorporation of new tools and practices. Indeed, many present-day indigenous-led management approaches and research activities walk backwards into the future by using or producing rigorous scientific evidence, and often involve incorporation of knowledge through collaboration with other indigenous or nonindigenous communities (see for example, Hilistis [Waterfall] et al. 2001, Bragg et al. 2009, Moller et al. 2009, Adams et al. 2014, Housty et al. 2014, Service et al. 2014, Cuerrier et al. 2015, Polfus et al. 2016, Atlas et al. 2017).

\section{Opportunities for learning}

The application of place-based approaches in areas where such values do not already exist presents opportunities for learning. In place-based societies, life is intertwined with the environment, so the notion of environmental management (and associated values) as a specialized activity separate from other aspects of life is largely irrelevant (Lertzman 2009, Berkes 2012, Turner 2014, Chatwood et al. 2017). Moreover, the values of place-based communities coevolved with practices. The implementation of values-led approaches in places without existing place-based peoples and practices, and over a much shorter period than observed in the examples provided herein, is a novel route. Work is needed to identify how existing place-supportive values might apply in new situations, to identify which additional values might prove useful for enabling place-based relationships, and to assess the circumstances in which this broad approach might be most effective, representing opportunities for adaptive learning (Jones et al. 2010). Moreover, further investigation into how place-based values might interact with or be incorporated into existing (or additional) laws in a given location might enable better systems of protection and management.

Additional insights might be gleaned by assessing systems where resumption or development of values-led foundations is occurring for the following: (a) similarities and differences in the specific values driving each, (b) how these systems differ from Western approaches, in terms of integration of guiding values, and (c) differences in how a foundation of values translates to realized differences in outcomes (as in Waller and Reo 2018) and interactions with place.

\section{Opportunities for scaling up}

In addition to developing values-led approaches at a local scale, there is the potential for much wider application at broader scales and to address cross-boundary issues. Many of the environmental problems facing humanity today are novel, e.g., plastic pollution, invasive species, and global anthropogenic climate change (Hobbs et al. 2009). Moreover, causes and effects might extend beyond knowledge currently held, e.g., ecosystems have shifted beyond conditions previously experienced and managed, and are driven by forces that extend beyond the places they are affecting. This suggests that incorporating all knowledge sources might be advantageous (Stephenson and Moller 2009). That new tools might be useful to understand, predict, and even interact with environments, however, does not negate the importance of building strong bonds between people and place; instead, 
Table 2. Guiding questions for conceptualizing or codifying a values-led management approach

Question
1. Who are knowledge holders and/or who has long-
term relationships with the place?

2. What are the values connected to the place?
Explanation

Identifying the people who have long-established relationships with the area of interest might be an important step in ensuring key values and knowledge are included. Although inclusivity of all interested community members is important, acknowledging and learning from indigenous and other place-based peoples is particularly significant.

Having values understood and explicitly described might help delineate the fundamental basis of agreements or disagreements. It might also facilitate disentangling which considerations are ultimately quantitative and determined directly by data, e.g., how many individuals are in the population of a particular species, versus those based on values, e.g., how should we structure our relationship with this species. For each identified value, it might be helpful to explore its meaning and origin, with knowledge holders defining its full context and implications. Working toward a shared definition for a given value, even within a community, might be helpful to clarify differing interpretations. This might be of particular importance in cases where not everyone in a given group comes from the same cultural context; a shared understanding of underlying values might help to build identity and understanding among the broader group. This may need to be an iterative process to ensure all important values have been recognized and explored.

3. Which values should be adopted?

Sometimes different values held by individual community members may not be aligned with one another, and decisions will have to be made about which values should underpin environmental management. When in doubt, participants might want to focus on values that reinforce their connections with local environments, respect for all aspects of the environment, and responsibility for nurturing and sustaining the natural systems.

4. How might the identified values translate into objectives?

This step addresses how underlying values might structure actionable objectives. For example, if an identified value is respect for a given species, which specific objectives might ensure that principle is upheld? Two respect-related objectives might include ensuring that (1) individuals of that species are not disrespected and (2) its populations are not overexploited.

Here, specific actions or behaviors are identified that might ensure objectives are met. How should people engage with the environment to best achieve objectives? In cases where placebased practices were recently discontinued, it might be helpful to identify whether there are opportunities for their resurgence.

Following from the previous example, one way to ensure populations are not overexploited might be to ensure harvesting does not happen at certain times of year so that breeding stock is maintained. Another might be to take only what is needed, which might have particularly important ramifications in commercial endeavors, e.g., commercial activities might look very different if yoked toward meeting a predetermined need vs. maximal exploitation, though how that would be operationalized remains an open question.

6. Are specific policies or laws needed to ensure these Laws and policies may need to be changed or adopted that support the practices identified in practices are followed? step 5. Following from the example above, one way to ensure people do not take more than they need or harvest at certain times of year or in certain places might be to develop monitoring systems and policies that lay these restrictions out explicitly, including associated penalties. In some cases, the laws or policies might not be new but instead those that have been discontinued recently, such as traditional methods and contexts of harvest.

A plan might be quickly forgotten if it is not shared broadly, and might not be actualized unless it inspires the community. It similarly might not have lasting effects if it does not inspire future generations, providing a foundation for multigenerational management. Guiding questions might include: how might the plan be communicated to different members of the community? What media might it be shared across? Can curriculum be developed to teach its insights to the next generation?
7. How can insights from the plan be shared effectively with the community? questions invite an exploratory approach, not a prescriptive one, and seek to distill the knowledge and values already held within communities to help guide visions toward future management goals. To develop these questions, we drew insights from existing Iwi Management Plans, the Haida management plan (Marine Planning Partnership Initiative 2015), a developing Heiltsuk values-led approach to wildlife management guided by Ğvilás, and work by coauthor Corey Bragg on a method used to distill valuesled approaches for Māori businesses. This approach might be used in (a) scenarios where communities already have established values and practices related to environmental management and are seeking to formalize and enact their approach based on their 
own laws, customs, and beliefs, e.g., decolonizing contexts; (b) scenarios where communities wish to sustain relationships with a place but do not yet have place-adapted values; and (c) scenarios where people have a united set of values, or a united vision, but have yet to translate these into specific management approaches.

\section{CONCLUSION}

Major and expanding global environmental problems suggest that humanity must fundamentally alter our overall relationship with the natural world, appreciate the ways in which our actions affect our environments, and develop values that guide more sustainable relationships with them. We have described how models already exist for such relationships, exemplified by existing values-led approaches associated with place-based peoples, many of which have been time-tested over millennia. Enabling the resumption of place-based relationships in areas where they have been recently interrupted, e.g., postcolonial indigenous communities, and developing similar approaches elsewhere provides considerable potential for applying deep leverage to shift social-ecological systems, facilitating fundamental change in humanity's relationships to environments. In turn, these relationships may contribute toward stemming the tide of global ecological crises. Ultimately, a broader recognition of the potential for values-led approaches to environmental management may be recognized as part of the wider arsenal of science, law, policy, and practice interventions that are needed to address today's social-ecological challenges.

\section{Responses to this article can be read online at:}

http://www.ecologyandsociety.org/issues/responses. php/10357

\section{Acknowledgments:}

We thank Henrik Moller, Jacinta Ruru, Larry Jorgenson, Pamela Wilson, Mara Andrews, Riria Allen, Douglas Neasloss, Tangiora Tawhara, Clyde Tallio, Qqs Projects Society, and the Heiltsuk Integrated Resource Management Department for helpful input and for facilitating this work. KAA was supported by a Vanier Fellowship with a Michael Smith Foreign Study Supplement, and by Chris T. Darimont and John D. Reynolds. We thank the anonymous reviewers who improved this work considerably.

\section{LITERATURE CITED}

Abson, D. J., J. Fischer, J. Leventon, J. Newig, T. Schomerus, U. Vilsmaier, H. von Wehrden, P. Abernethy, C. D. Ives, N. W. Jager, and D. J. Lang. 2017. Leverage points for sustainability transformation. Ambio 46(1):30-39. http://dx.doi.org/10.1007/ s13280-016-0800-y

Adams, M. S., J. Carpenter, J. A. Housty, D. Neasloss, P. C. Paquet, C. Service, J. Walkus, and C. T. Darimont. 2014. Towards increased engagement between academic and indigenous community partners in ecological research. Ecology and Society 19(3):5. http://dx.doi.org/10.5751/ES-06569-190305

Adams, M. S., C. N. Service, A. Bateman, M. Bourbonnais, K. A. Artelle, T. Nelson, P. C. Paquet, T. Levi, and C. T. Darimont.
2017. Intrapopulation diversity in isotopic niche over landscapes: spatial patterns inform conservation of bear-salmon systems. Ecosphere 8(6):e01843. http://dx.doi.org/10.1002/ecs2.1843

Altieri, M. A. 2004. Linking ecologists and traditional farmers in the search for sustainable agriculture. Frontiers in Ecology and the Environment 2(1):35-42. http://dx.doi.org/10.1890/1540-9295 (2004)002[0035:LEATFI]2.0.CO;2

Anderson, E. N. 1996. Ecologies of the heart: emotion, belief, and the environment. Oxford University Press, New York, New York, USA.

Anderson, M. W., M. F. Teisl, and C. L. Noblet. 2016. Whose values count: Is a theory of social choice for sustainability science possible? Sustainability Science 11(3):373-383. http://dx.doi. org/10.1007/s11625-015-0345-1

Artelle, K. A., S. C. Anderson, A. B. Cooper, P. C. Paquet, J. D. Reynolds, and C. T. Darimont. 2013. Confronting uncertainty in wildlife management: performance of grizzly bear management. PLOS ONE 8(11):e78041. http://dx.doi.org/10.1371/journal. pone.0078041

Artelle, K. A., S. C. Anderson, J. D. Reynolds, A. B. Cooper, P. C. Paquet, and C. T. Darimont. 2016. Ecology of conflict: marine food supply affects human-wildlife interactions on land. Scientific Reports 6:25936. http://dx.doi.org/10.1038/srep25936

Artelle, K. A., J. D. Reynolds, P. C. Paquet, and C. T. Darimont. 2014. When science-based management isn't. Science 343 (6177):1311-1311. http://dx.doi.org/10.1126/science.343.6177.1311a

Artelle, K. A., J. D. Reynolds, A. Treves, J. C. Walsh, P. C. Paquet, and C. T. Darimont. 2018. Hallmarks of science missing from North American wildlife management. Science Advances 4(3): eaao0167. http://dx.doi.org/10.1126/sciadv.aao0167

Atlas, W. I., W. G. Housty, A. Béliveau, B. DeRoy, G. Callegari, M. Reid, and J. W. Moore. 2017. Ancient fish weir technology for modern stewardship: lessons from community-based salmon monitoring. Ecosystem Health and Sustainability 3(6):1341284. http://dx.doi.org/10.1080/20964129.2017.1341284

Atleo, E. R. 2011. Principles of Tsawalk. An indigenous approach to global crisis. UBC Press, Vancouver, British Columbia, Canada.

Augustine, S., and P. Dearden. 2014. Changing paradigms in marine and coastal conservation: a case study of clam gardens in the Southern Gulf Islands, Canada. Canadian Geographer / Le Géographe canadien 58(3):305-314. https://doi.org/10.1111/ cag. 12084

Barr, S., and A. W. Gilg. 2007. A conceptual framework for understanding and analyzing attitudes towards environmental behaviour. Geografiska Annaler: Series B, Human Geography 89 (4):361-379. http://dx.doi.org/10.1111/j.1468-0467.2007.00266.x

Belich, J. 2007. Making peoples: a history of the New Zealanders, from Polynesian settlement to the end of the nineteenth century. Penguin Group, Auckland, New Zealand.

Berkes, F. 2012. Sacred ecology: traditional ecological knowledge and resource management. Third edition. Taylor and Francis, Philadelphia, Pennsylvania, USA. 
Berkes, F., and N. J. Turner. 2006. Knowledge, learning and the evolution of conservation practice for social-ecological system resilience. Human Ecology 34(4):479-494. http://dx.doi. org/10.1007/s10745-006-9008-2

Betts, M. G., C. Wolf, W. J. Ripple, B. Phalan, K. A. Millers, A. Duarte, S. H. M. Butchart, and T. Levi. 2017. Global forest loss disproportionately erodes biodiversity in intact landscapes. Nature 547(7664):441-444. http://dx.doi.org/10.1038/nature23285

Bhattacharyya, J., and S. Slocombe. 2017. Animal agency: wildlife management from a kincentric perspective. Ecosphere 8(10): e01978. http://dx.doi.org/10.1002/ecs2.1978

Bird, R. B., and D. Nimmo. 2018. Restore the lost ecological functions of people. Nature Ecology \& Evolution 2:1050-1052. http://dx.doi.org/10.1038/s41559-018-0576-5

Bragg, C., S. McKechnie, J. Newman, D. Fletcher, H. Moller, and D. Scott. 2009. Variation in abundance and harvest of Sooty Shearwaters (Puffinus griseus) by Rakiura Māori on Putauhinu Island, New Zealand. New Zealand Journal of Zoology 36 (3):275-289. http://dx.doi.org/10.1080/03014220909510155

British Columbia Ministry of Environment, Fish, Wildlife and Habitat Branch. 2010. Grizzly bear hunting: frequently asked questions. British Columbia Ministry of Environment, Fish, Wildlife and Habitat Branch, Victoria, British Columbia, Canada. [online] URL: http://www.env.gov.bc.ca/fw/wildlife/ management-issues/docs/grizzly bear faq.pdf

Brown, F., and Y. K. Brown. 2009. Staying the course, staying alive: coastal First Nations fundamental truths: biodiversity, stewardship and sustainability. Biodiversity BC.

Bryan, H. M., C. T. Darimont, P. C. Paquet, K. E. WynneEdwards, and J. E. G. Smits. 2013. Stress and reproductive hormones in grizzly bears reflect the nutritional benefits and social consequences of a salmon foraging niche. PLOS ONE 8 (11):e80537. http://dx.doi.org/10.1371/journal.pone.0080537

Bryan, H. M., C. T. Darimont, P. C. Paquet, K. E. WynneEdwards, and J. E. G. Smits. 2014. Stress and reproductive hormones reflect inter-specific social and nutritional conditions mediated by resource availability in a bear-salmon system. Conservation Physiology 2(1):1-18. http://dx.doi.org/10.1093/ conphys/cou010

Cattet, M., J. Boulanger, G. Stenhouse, R. A. Powell, and M. J. Reynolds-Hogland. 2008. An evaluation of long-term capture effects in ursids: implications for wildlife welfare and research. Journal of Mammalogy 89(4):973-990. http://dx.doi.org/10.1644/08MAMM-A-095.1

Ceballos, G., P. R. Ehrlich, and R. Dirzo. 2017. Biological annihilation via the ongoing sixth mass extinction signaled by vertebrate population losses and declines. Proceedings of the National Academy of Sciences 114(30):E6089-E6096. http://dx. doi.org/10.1073/pnas.1704949114

Chan, K. M. A., P. Balvanera, K. Benessaiah, M. Chapman, S. Díaz, E. Gómez-Baggethun, R. Gould, N. Hannahs, K. Jax, S. Klain, G. W. Luck, B. Martín-López, B. Muraca, B. Norton, K. Ott, U. Pascual, T. Satterfield, M. Tadaki, J. Taggart, and N. Turner. 2016. Opinion: Why protect nature? Rethinking values and the environment. Proceedings of the National Academy of Sciences 113(6):1462-1465. http://dx.doi.org/10.1073/pnas. 1525002113

Chatwood, S., F. Paulette, G. R. Baker, A. M. A. Eriksen, K. L. Hansen, H. Eriksen, V. Hiratsuka, J. Lavoie, W. Lou, I. Mauro, J. Orbinski, N. Pambrun, H. Retallack, and A. Brown. 2017. Indigenous values and health systems stewardship in circumpolar countries. International Journal of Environmental Research and Public Health 14(12):1462. http://dx.doi.org/10.3390/ijerph14121462

Clark, D. A., and D. S. Slocombe. 2009. Respect for grizzly bears: an Aboriginal approach for co-existence and resilience. Ecology and Society 14(1):42. http://dx.doi.org/10.5751/ES-02892-140142

Clayoquot Sound Scientific Panel. 1995. Sustainable ecosystem management in Clayoquot Sound: planning and practices. Report 5. Clayoquot Sound Scientific Panel, Victoria, British Columbia, Canada.

Comberti, C., T. F. Thornton, V. Wyllie de Echeverria, and T. Patterson. 2015. Ecosystem services or services to ecosystems? Valuing cultivation and reciprocal relationships between humans and ecosystems. Global Environmental Change 34:247-262. http:// dx.doi.org/10.1016/j.gloenvcha.2015.07.007

Cuerrier, A., N. J. Turner, T. C. Gomes, A. Garibaldi, and A. Downing. 2015. Cultural keystone places: conservation and restoration in cultural landscapes. Journal of Ethnobiology 35 (3):427-448. http://dx.doi.org/10.2993/0278-0771-35.3.427

Darimont, C. T., K. A. Artelle, F. Moola, and P. C. Paquet. 2017. Trophy hunting: science on its own can't dictate policy. Nature 551(7682):565. http://dx.doi.org/10.1038/d41586-017-07553-6

Darimont, C. T., H. M. Bryan, S. M. Carlson, M. D. Hocking, M. MacDuffee, P. C. Paquet, M. H. H. Price, T. E. Reimchen, J. D. Reynolds, and C. C. Wilmers. 2010. Salmon for terrestrial protected areas. Conservation Letters 3(6):379-389. http://dx.doi. org/10.1111/j.1755-263X.2010.00145.X

Darimont, C. T., P. C. Paquet, A. Treves, K. A. Artelle, and G. Chapron. 2018. Political populations of large carnivores. Conservation Biology 32(3):747-749. http://dx.doi.org/10.1111/ cobi.13065

Darimont, C., T. Reimchen, H. Bryan, and P. Paquet. 2008. Faecal-centric approaches to wildlife ecology and conservation; methods, data and ethics. Wildlife Biology in Practice 4(2):73-87.

Davis, W. 2009. The wayfinders: why ancient wisdom matters in the modern world. House of Anansi, Toronto, Ontario, Canada.

Dick, J., J. Stephenson, R. Kirikiri, H. Moller, and R. Turner. 2012. Listening to the Kaitiaki: consequences of the loss of abundance and biodiversity of coastal ecosystems in Aotearoa New Zealand. MAI Journal 1(2):117-130.

Durie, M. 2010. Outstanding universal value: how relevant is indigeneity. Pages 239-250 in R. Selby, P. Moore, and M. Mulholland, editors. Māori and the environment: Kaitiaki. Huia, Wellington, Aotearoa, New Zealand.

Garibaldi, A., and N. Turner. 2004. Cultural keystone species: implications for ecological conservation and restoration. Ecology and society 9(3):1. http://dx.doi.org/10.5751/ES-00669-090301 
Gauvreau, A., D. Lepofsky, M. Rutherford, and M. Reid. 2017. "Everything revolves around the herring": the Heiltsuk-herring relationship through time. Ecology and Society 22(2):10. http:// dx.doi.org/10.5751/ES-09201-220210

Green, T. L. 2007. Improving human wellbeing and ecosystem health on BC's coast: the challenge posed by historic resource extraction. Journal of Bioeconomics 9(3):245. http://dx.doi. org/10.1007/s10818-007-9024-3

Groesbeck, A. S., K. Rowell, D. Lepofsky, and A. K. Salomon. 2014. Ancient clam gardens increased shellfish production: adaptive strategies from the past can inform food security today. PLoS ONE 9(3):e91235. https://doi.org/10.1371/journal.pone.0091235

Harmsworth, G., and S. Awatere. 2013. Indigenous Māori knowledge and perspectives of ecosystems. Pages 274-286 in J. R. Dymond, editor. Ecosystem services in New Zealand - conditions and trends. Manaaki Whenua, Lincoln, New Zealand.

Harris, C. 2011. The resettlement of British Columbia: essays on colonialism and geographical change. UBC Press, Vancouver, British Columbia, Canada.

Heiltsuk Tribal Council. 2005. For our children's tomorrows Heiltsuk land use plan. Heiltsuk Tribal Council, Waglisla (Bella Bella), British Columbia, Canada.

Hilistis (Waterfall), P., D. Hopwood, and I. Gill. 2001. People and the land. Pages 100-127 in Ecotrust Canada, editor. North of caution. Ecotrust Canada, Vancouver, British Columbia, Canada.

Hobbs, R. J., E. Higgs, and J. A. Harris. 2009. Novel ecosystems: implications for conservation and restoration. Trends in Ecology \& Evolution 24(11):599-605. http://dx.doi.org/10.1016/j.tree.2009.05.012

Holdaway, R. N., and C. Jacomb. 2000. Rapid extinction of the moas (Aves: Dinornithiformes): model, test, and implications. Science 287(5461):2250-2254. http://dx.doi.org/10.1126/ science.287.5461.2250

Hook, G. R., T. Waaka, and L. P. Raumati. 2007. Mentoring Māori within a Pākehā framework. MAI Review LW 1(3):13.

Horwitz, P., and M. Calver. 1998. Credible science? Evaluating the regional forest agreement process in Western Australia. Australian Journal of Environmental Management 5(4):213-225. http://dx.doi.org/10.1080/14486563.1998.10648420

Housty, W. G., A. Noson, G. W. Scoville, J. Boulanger, R. M. Jeo, C. T. Darimont, and C. E. Filardi. 2014. Grizzly bear monitoring by the Heiltsuk people as a crucible for First Nation conservation practice. Ecology and Society 19(2):70. http://dx.doi.org/10.5751/ ES-06668-190270

Hutchison, A. 2014. The Whanganui River as a legal person. Alternative Law Journal 39(3):179-182. http://dx.doi. org/10.1177/1037969X1403900309

Jackley, J., L. Gardner, A. F. Djunaedi, and A. K. Salomon. 2016. Ancient clam gardens, traditional management portfolios, and the resilience of coupled human-ocean systems. Ecology and Society 21(4):20. https://doi.org/10.5751/ES-08747-210420

Johnson, L. M., and E. S. Hunn. 2010. Landscape ethnoecology: concepts of biotic and physical space. Berghahn Books, New York, New York, USA.
Jones, J. T. 2000. We looked after all the salmon streams: traditional Heiltsuk cultural stewardship of salmon and salmon streams, a preliminary assessment. Thesis. University of Victoria, Victoria, British Columbia, Canada.

Jones, R., C. Rigg, and L. Lee. 2010. Haida marine planning: First Nations as a partner in marine conservation. Ecology and Society 15(1):12. http://dx.doi.org/10.5751/ES-03225-150112

Ka'ai-Mahuta, R. 2011. The impact of colonisation on te reo Māori: a critical review of the state education system. Te Kaharoa 4(1):195-225. http://dx.doi.org/10.24135/tekaharoa.v4i1.117

Kahui, V., and A. C. Richards. 2014. Lessons from resource management by indigenous Maori in New Zealand: governing the ecosystems as a commons. Ecological Economics 102:1-7. http://dx.doi.org/10.1016/j.ecolecon.2014.03.006

Kawharu, M. 2000. Kaitiakitanga: a Maori anthropological perspective of the Maori socio-environmental ethic of resource management. Journal of the Polynesian Society 109(4):349-370.

Kawharu, M. 2010. Environment as a marae locale. Pages 221-237 in R. Selby, P. Moore, and M. Mulholland, editors. Māori and the environment: Kaitiaki. Huia, Wellington, Aotearoa, New Zealand.

Kimmerer, R. 2013. Braiding sweetgrass: indigenous wisdom, scientific knowledge and the teachings of plants. Milkweed Editions, Minneapolis, Minnesota, USA.

King, T. 2012. The inconvenient Indian: a curious account of Native people in North America. Doubleday Canada, Toronto, Ontario, Canada.

Kitson, J. C., and H. Moller. 2008. Looking after your ground: resource management practice by Rakiura Maori titi harvesters. Papers and Proceedings of the Royal Society of Tasmania 142 (1):161-176. http://dx.doi.org/10.26749/rstpp.142.1.161

Lemelin, R. H., R. Koster, and N. Youroukos. 2015. Tangible and intangible indicators of successful aboriginal tourism initiatives: a case study of two successful aboriginal tourism lodges in northern Canada. Tourism Management 47:318-328. http://dx. doi.org/10.1016/j.tourman.2014.10.011

Lepofsky, D., N. F. Smith, N. Cardinal, J. Harper, M. Morris, E. White, R. Bouchard, D. I. Kennedy, A. K. Salomon, M. Puckett, and K. Rowell. 2015. Ancient shellfish mariculture on the Northwest Coast of North America. American Antiquity 80 (2):236-259. https://doi.org/10.7183/0002-7316.80.2.236

Lertzman, K. 2009. The paradigm of management, management systems, and resource stewardship. Journal of Ethnobiology 29 (2):339-358. http://dx.doi.org/10.2993/0278-0771-29.2.339

Lyver, P. O., A. Akins, H. Phipps, V. Kahui, D. R. Towns, and H. Moller. 2016. Key biocultural values to guide restoration action and planning in New Zealand. Restoration Ecology 24(3):314-323. http://dx.doi.org/10.1111/rec.12318

Magallanes, C. J. I. 2015. Nature as an ancestor: two examples of legal personality for nature in New Zealand. VertigO: la revue électronique en sciences de l'environnement 22:1-15. http://dx.doi. org/10.4000/vertigo.16199

Mangel, M. 2011. An assessment of Japanese whale research programs under special permit in the Antarctic (JARPA, JARPA 
II) as Programs for Purposes of Scientific Research in the Context of Conservation and Management of Whales. Pages 334-388 Whaling in the Antarctic (Australia v. Japan). Memorial of Australia. International Court of Justice, The Hague, The Netherlands.

Manuel, A., and G. C. R. M. Derrickson. 2015. Unsettling Canada: a national wake-up call. Between the Lines, Toronto, Ontario, Canada.

Marine Planning Partnership Initiative. 2015. Haida Gwaii Marine Plan. Marine Planning Partnership Initiative, British Columbia, Canada.

Martin, J.-L., V. Maris, and D. S. Simberloff. 2016. The need to respect nature and its limits challenges society and conservation science. Proceedings of the National Academy of Sciences 113 (22):6105-6112. http://dx.doi.org/10.1073/pnas. 1525003113

Mathews, D. L., and N. J. Turner. 2017. Ocean cultures: Northwest Coast ecosystems and indigenous management systems. Pages 169-206 in P. S. Levin and M. R. Poe, editors. Conservation for the Anthropocene ocean. Interdisciplinary Science in the Support of Nature and People. Elsevier, London, UK. http:// dx.doi.org/10.1016/B978-0-12-805375-1.00009-X

McCarthy, A., C. Hepburn, N. Scott, K. Schweikert, R. Turner, and H. Moller. 2014. Local people see and care most? Severe depletion of inshore fisheries and its consequences for Māori communities in New Zealand. Aquatic Conservation: Marine and Freshwater Ecosystems 24(3):369-390. http://dx.doi.org/10.1002/ $\underline{\text { aqc. } 2378}$

McIntosh, N., K. Maly, and J. N. Kittinger. 2014. Integrating traditional ecological knowledge and community engagement in marine mammal protected areas. Pages 163-174 in J. Higham, L. Bejder, and R. Williams, editors. Whale-watching: sustainable tourism and ecological management. Cambridge University Press, Cambridge, UK. http://dx.doi.org/10.1017/CBO9781139018166.014

Mead, H. M. 2003. Tikanga Māori: living by Māori values. Huia, Wellington, Aotearoa, New Zealand.

Meadows, D. 1999. Leverage points: places to intervene in a system. The Sustainability Institute, Hartland, Vermont, USA.

Mihinui, H. B. 2002. Hutia te rito o te harakeke: a flax root understanding of resource management. Pages 21-33 in M. Kawharu, editor. Whenua: managing our resources. Reed, Auckland, New Zealand.

Mikaere, A. 2011. Colonising myths-Maori realities: He rukuruku whakaaro. Huia, Wellington, Aotearoa, New Zealand.

Moller, H., P. O'Blyver, C. Bragg, J. Newman, R. Clucas, D. Fletcher, J. Kitson, S. McKechnie, D. Scott, and Rakiura Titi Islands Administering Body. 2009. Guidelines for cross-cultural participatory action research partnerships: a case study of a customary seabird harvest in New Zealand. New Zealand Journal of Zoology 36(3):211-241. http://dx.doi.org/10.1080/03014220909510152

Mollison, B., R. M. Slay, C. Bourgignon, and L. Bourguignon. 1991. Introduction to permaculture. Tagari, Tyalgum, Australia.

Muckle, B., and A. Gauvreau. 2017. Populating the Pacific Northwest. Anthropology News 58(2):e148-e151. http://dx.doi. org/10.1111/AN.412
Murray, G., and L. King. 2012. First Nations values in protected area governance: Tla-o-qui-aht tribal parks and Pacific Rim National Park Reserve. Human Ecology 40(3):385-395. https:// doi.org/10.1007/s10745-012-9495-2

National Science Challenges. 2017. Sustainable seas national science challenge. National Science Challenges, New Zealand. http://sustainableseaschallenge.co.nz/

Nelson, M. P., J. A. Vucetich, P. C. Paquet, and J. K. Bump. 2011. An inadequate construct? Wildlife Professional Summer 5:58-60.

New Zealand Government. 2016. Te Awa Tupua (Whanganui River Claims Settlement) Bill 129-2. New Zealand Parliament, Wellington, New Zealand.

O'Riordan, T. 2014. Environmental science for environmental management. Routledge, London, UK.

Panelli, R., and G. Tipa. 2007. Placing well-being: a Maori case study of cultural and environmental specificity. EcoHealth 4 (4):445-460. http://dx.doi.org/10.1007/s10393-007-0133-1

Paringatai, K. 2014. Māori identity development outside of tribal environments. Aotearoa New Zealand Social Work 26(1):47-54. http://dx.doi.org/10.11157/anzswj-vol26iss1id54

Parsons, M., J. Nalau, and K. Fisher. 2017. Alternative perspectives on sustainability: indigenous knowledge and methodologies. Challenges in Sustainability 5(1):7-14. http://dx. doi.org/10.12924/cis2017.05010007

Platt, J. R. 1964. Strong inference. Science 146(3642):347-353. http://dx.doi.org/10.1126/science.146.3642.347

Polfus, J. L., M. Manseau, D. Simmons, M. Neyelle, W. Bayha, F. Andrew, L. Andrew, C. F. C. Klütsch, K. Rice, and P. Wilson. 2016. Leghágots'enetę (learning together): the importance of indigenous perspectives in the identification of biological variation. Ecology and Society 21(2):18. http://dx.doi. org/10.5751/ES-08284-210218

Popescu, V. D., K. A. Artelle, M. I. Pop, S. Manolache, and L. Rozylowicz. 2016. Assessing biological realism of wildlife population estimates in data-poor systems. Journal of Applied Ecology 53(4):1248-1259. http://dx.doi.org/10.1111/1365-2664.12660

Price, K., A. Roburn, and A. MacKinnon. 2009. Ecosystem-based management in the Great Bear Rainforest. Forest Ecology and Management 258(4):495-503. http://dx.doi.org/10.1016/j.

foreco.2008.10.010

Rangihau, J. 1992. Being Maori. Pages 185-190 in M. King, editor. Te ao hurihuri: aspects of Maoritanga. Reed Books, Wellington, New Zealand.

Ripple, W. J., C. Wolf, T. M. Newsome, M. Galetti, M. Alamgir, E. Crist, M. I. Mahmoud, and W. F. Laurance. 2017. World scientists' warning to humanity: a second notice. BioScience 67 (12):1026-1028. http://dx.doi.org/10.1093/biosci/bix125

Roberts, M., W. Norman, N. Minhinnick, D. Wihongi, and C. Kirkwood. 1995. Kaitiakitanga: Māori perspectives on conservation. Pacific Conservation Biology 2(1):7-20. http://dx. doi.org/10.1071/PC950007

Rotarangi, S., and D. Russell. 2009. Social-ecological resilience thinking: Can indigenous culture guide environmental 
management? Journal of the Royal Society of New Zealand 39 (4):209-213. http://dx.doi.org/10.1080/03014220909510582

Ruckstuhl, K., L. Carter, L. Easterbrook, A. R. Gorman, H. Rae, J. Ruru, D. Ruwhiu, J. Stephenson, A. Suszko, M. ThompsonFawcett, and R. Turner. 2013. Māori and mining. Māori and Mining Research Team, Dunedin, New Zealand.

Ruru, J. A. 2012. Settling indigenous place: reconciling legal fictions in governing Canada and Aotearoa New Zealand's national parks. Dissertation. University of Victoria, Victoria, British Columbia, Canada.

Ruru, J. 2014. Tūhoe-Crown settlement - Te Urewera Act 2014. Māori Law Review.

Service, C. N., M. S. Adams, K. A. Artelle, P. Paquet, L. V. Grant, and C. T. Darimont. 2014. Indigenous knowledge and science unite to reveal spatial and temporal dimensions of distributional shift in wildlife of conservation concern. PLOS ONE 9(7): e101595. http://dx.doi.org/10.1371/journal.pone.0101595

Simpson, L. 2001. Traditional ecological knowledge: marginalization, appropriation and continued disillusion. Pages 132-139 in Indigenous Knowledge Conference, University of Saskatchewan, Saskatoon, Saskatchewan, Canada. [online] URL: http://iportal.usask.ca/purl/IKC-2001-Simpson.pdf

Sinclair, M., and Truth and Reconciliation Commission (TRC) members. 2015. Final Report of the Truth and Reconciliation Commission of Canada. Truth and Reconciliation Commission of Canada, Winnipeg, Manitoba, Canada.

Spiller, C., and S. Bhowmick. 2014. Whale watch Kaikoura-New Zealand. Pages 141-155 in J. Hayton, C. Salvato, and M. J. Manimala, editors. Global entrepreneurship: case studies of entrepreneurial firms operating around the world. Routledge, New York, New York, USA.

Stephenson, J. 2002. The management of a Māori-owned resource. Pages 169-215 in M. Kawharu, editor. Whenua: managing our resources. Reed, Auckland, New Zealand.

Stephenson, J., M. Abbott, and J. Ruru. 2010. Beyond the scene: landscape and identity in Aotearoa New Zealand. Otago University Press, Dunedin, New Zealand.

Stephenson, J., F. Berkes, N. Turner, and J. Dick. 2014. Biocultural conservation of marine ecosystems: examples from New Zealand and Canada. Indian Journal of Traditional Knowledge 13 (2):257-265.

Stephenson, J., and H. Moller. 2009. Cross-cultural environmental research and management: challenges and progress. Journal of the Royal Society of New Zealand 39 (4):139-149. http://dx.doi.org/10.1080/03014220909510567

Sullivan, P. J., J. Acheson, P. L. Angermeier, T. Faast, J. Flemma, C. M. Jones, E. E. Knudsen, T. J. Minello, D. H. Secor, R. Wunderlich, and B. A. Zanetell. 2006. Defining and implementing best available science for fisheries and environmental science, policy, and management. Fisheries 31(9):460-465.

Tapsell, P. 2014. Tribal Marae: crisis? What crisis? Pages 35-64 in M. Kawharu, editor. Maranga Mai! Te Reo and Marae in crisis? Auckland University Press, Auckland, New Zealand.
Te Rūnanga o Kaikōura. 2007. Te Poha o Tohu Raumati Te Rūnanga o Kaikōura Environmental Management Plan. Te Rūnanga o Kaikōura, Takahanga Marae Kaikōura, New Zealand.

Thøgersen, J., and S. C. Grunert-Beckmann. 1997. Values and attitude formation towards emerging attitude objects: from recycling to general, waste minimizing behavior. ACR North American Advances 24:182-189.

Thompson-Fawcett (Ngāti Whātua), M., Ruru (Ngāti Raukawa ki Waikato, Ngāi Ranginui ki Tauranga, Ngāti Maniapoto), and G. Tipa (Ngāi Tahu). 2017. Indigenous resource management plans: transporting non-indigenous people into the indigenous world. Planning Practice \& Research 32(3):259-273. http://dx. doi. org/10.1080/02697459.2017.1308641

Thornton, T., D. Deur, and H. Kitka Sr. 2015. Cultivation of salmon and other marine resources on the Northwest Coast of North America. Human Ecology 43(2):189-199. http://dx.doi. org/10.1007/s10745-015-9747-Z

Timoti, P., P. O'B. Lyver, R. Matamua, C. Jones, and B. Tahi. 2017. A representation of a Tuawhenua worldview guides environmental conservation. Ecology and Society 22(4):20. http:// dx.doi.org/10.5751/ES-09768-220420

Treves, A., G. Chapron, J. V. López-Bao, C. Shoemaker, A. R. Goeckner, and J. T. Bruskotter. 2017. Predators and the public trust. Biological Reviews 92(1):248-270. http://dx.doi.org/10.1111/ brv. 12227

Turner, K., and C. Bitonti. 2011. Conservancies in British Columbia, Canada: bringing together protected areas and First Nations' interests. International Indigenous Policy Journal 2(2):3.

Turner, N. 2005. The Earth's blanket: traditional teachings for sustainable living. Douglas \& McIntyre, Vancouver, British Columbia, Canada.

Turner, N. 2014. Ancient pathways, ancestral knowledge: ethnobotany and ecological wisdom of indigenous peoples of northwestern North America. McGill-Queen's University Press, Montréal, Québec, Canada.

Turner, N. J., and F. Berkes. 2006. Coming to understanding: developing conservation through incremental learning in the Pacific Northwest. Human Ecology 34(4):495-513. http://dx. doi. org/10.1007/s10745-006-9042-0

Turner, N. J., F. Berkes, J. Stephenson, and J. Dick. 2013. Blundering intruders: extraneous impacts on two indigenous food systems. Human Ecology 41(4):563-574. http://dx.doi.org/10.1007/ s10745-013-9591-y

Turner, N. J., R. Gregory, C. Brooks, L. Failing, and T. Satterfield. 2008. From invisibility to transparency: identifying the implications. Ecology and Society 13(2):7. http://dx.doi. org/10.5751/ES-02405-130207

Turner, N. J., M. B. Ignace, and R. Ignace. 2000. Traditional ecological knowledge and wisdom of aboriginal peoples in British Columbia. Ecological Applications 10(5):1275-1287. http://dx. doi.org/10.1890/1051-0761(2000)010[1275:TEKAWO]2.0.CO;2 
Turner, N., and P. R. Spalding. 2013. "We might go back to this": drawing on the past to meet the future in northwestern North American indigenous communities. Ecology and Society 18(4):29. http://dx.doi.org/10.5751/ES-05981-180429

UN General Assembly. 2007. United Nations declaration on the rights of indigenous peoples. United Nations, New York, New York, USA.

Vitousek, P. M., H. A. Mooney, J. Lubchenco, and J. M. Melillo. 1997. Human domination of Earth's ecosystems. Science 277 (5325):494-499. http://dx.doi.org/10.1126/science.277.5325.494

Waitangi Tribunal. 2011. Ko Aotearoa tēnei: a report into claims concerning New Zealand law and policy affecting Māori culture and identity. Waitangi Tribunal, Wellington, New Zealand.

Waller, D. M., and N. J. Reo. 2018. First stewards: ecological outcomes of forest and wildlife stewardship by indigenous peoples of Wisconsin, USA. Ecology and Society 23(1):45. http:// dx.doi.org/10.5751/ES-09865-230145

Walter, R., H. Buckley, C. Jacomb, and E. Matisoo-Smith. 2017. Mass migration and the Polynesian settlement of New Zealand. Journal of World Prehistory 30(4):351-376. http://dx.doi. org/10.1007/s10963-017-9110-y

Wehi, P., M. Cox, T. Roa, and H. Whaanga. 2013. Marine resources in Māori oral tradition: He kai moana, he kai mā te hinengaro. Journal of Marine and Island Cultures 2(2):59-68. http://dx.doi.org/10.1016/j.imic.2013.11.006

Wehi, P. M., M. P. Cox, T. Roa, and H. Whaanga. 2018. Human perceptions of megafaunal extinction events revealed by linguistic analysis of indigenous oral traditions. Human Ecology 1-10. https://doi.org/10.1007/s10745-018-0004-0

West, J. 2017. The face of nature: an environmental history of the Otago Peninsula. Otago University Press, Dunedin, New Zealand.

West Coast Environmental Law. [date unknown]. RELAW: Revitalizing indigenous law for land, air and water. West Coast Environmental Law, Vancouver, British Columbia, Canada. [online] URL: https://www.wcel.org/our-work/relaw-revitalizingindigenous-law-land-air-and-water

White, X. E. A. F. 2006. Heiltsuk stone fish traps: products of my ancestor's labour. Thesis, Simon Fraser University, Burnaby, British Columbia, Canada.

Wilmshurst, J. M., A. J. Anderson, T. F. G. Higham, and T. H. Worthy. 2008. Dating the late prehistoric dispersal of Polynesians to New Zealand using the commensal Pacific rat. Proceedings of the National Academy of Sciences 105(22):7676-7680. http://dx. doi.org/10.1073/pnas.0801507105

Yohannan, A. 2016. The Standing Rock Sioux Indians: an inconvenience for the Black Gold recent developments. University of Baltimore Journal of Land and Development 6:19-32. 